\title{
Using Board Games Activities in Developing Iraqi EFL Preparatory School Students' Performance in Reading Skills
}

Mohammed Jassim H ussein, College of Basic Education, University of Babylon, Iraq mohammad.aldelemy@gmail.com

Ahmed Rudhwan Selman, College of Basic Education, University of Babylon, Iraq ahmedrawdhan68@gmail.com

Abd Ali N ayef Hassan, College of Basic Education, University of Babylon, Iraq

nayefhasan@yahoo.com

\begin{abstract}
Learning a second language can be challenging and demanding, especially for teachers. They must continuously innovate and improve their teaching by integrating new strategies and techniques into the classroom environment. Hence, the present study intends to examine the effect of board games activities on Iraqi Preparatory school students' reading skills. A quantitative research method is adopted, and a sample of (30) preparatory school students is randomly chosen to exemplify the two sets of the research (the control and experimental groups). The study adopts a pre-test post-test design to measure the influence of the strategy. The first hypothesis is accepted, and the researcher concluded that indeed board games activities help in developing the students' reading skills; however, other studies could concur or find different results.
\end{abstract}

Keywords: board games, activities, EFL preparatory school, performance, reading skills

Published: 2021-09-26

Doi: https:/ / doi.org/ 10.24127/ sociometry.v1i1.1479

\section{How to Cite:}

Hussein, M., Selman, A., \& Hassan, A. A. (2021). Using Board Games Activities in Developing Iraqi EFL Preparatory School Students' Performance in Reading Skills. Sociometry Journal of Social Science, Art and Humanity, 1(1). https:/ / doi.org/ 10.24127/ sociometry.v1i1.1479

Issue: Vol 1 No 1 (2021)

Section: Articles

(c) (1)

Copyright (c) 2021 Sociometry Journal of Social Science, Art and Humanity

This work is licensed under a Creative Commons Attribution 4.0 International License. 


\section{INTRODUCTION}

Reading is one of the essential skills, and it needs to be learned besides other skills: listening, speaking, and writing. Maxom (2009: 139) states that reading has a leading role in teaching language to enhance students' listening, speaking, and writing skills. Reading skill affects the other skills in the learning process. Reading has a great significance in learning for the following reasons: it helps the learner think in the new language. Through reading, the learner can build a better vocabulary " (Y Ildıım, 2010)".

Reading may be the only way for the learner to use the English language as a non-native language. It makes the learner more comfortable with the written English language. Also, it helps the learner who plans to study in an English-speaking society to communicate easily with the native speakers of that society (Mikulecky and Jeffries, 1986: 1).

Intensive reading usually takes place in the classroom; it refers to reading for details. Intensive reading usually goes along with classroom activities (D ehham,2021). Students are asked to look for selections from poems, novels, plays, and newspapers. Therefore, the purpose will limit the type of reading (Harmer, 2007: 100). Readers may read for getting information from materials hard to understand. In this way, they read slowly to comprehend. Extensive reading refers to reading which students can often do outside the classroom. Students may read material related to novels, magazines, newspapers (Harmer, 2007: 99). In this type, readers read for pleasure, with more speed in reading.

Reading aloud takes place in some classrooms. A significant number of students think that reading aloud can help them understand the text (Lewis, 1999: 188). It has a significant role in teaching. It is recommended for the primary level rather than the secondary level. If learners do not have enough reading aloud practicing early, they will face difficulties in the secondary stage. Reading aloud is helpful to develop speaking, pronouncing, or expressing ideas (Praveen and Rajan, 2013: 120-22) (D ehham, Bairamani \&, Shreeb,.2020).

Silent reading has an essential role in teaching English. Teachers can use it to develop students' ability to read correctly. It can save time since all learners read at the same time. It makes leamers very active if the subject matter is interesting (Ibid: 122-123). The students have difficulties comprehending the meaning (Lyon, Shywitz \& Shywitz, 2003). Napa (1991) states that many ways can be used to develop students' reading skills." Also, it can be used many different techniques, such as picture, crossword puzzle, song, game, text, board games and translation for teaching reading skills" (Rahoomi et al., 2019). One of these techniques is by using Board Games.

"Board Games are a an interesting technique to pick up new vocabulary and play with the vocabulary that has already familiar." "They contain fantasy, ritual, competition, and luck that are interesting for students." On the other hand, games reduce boredom. "When board games are used, the situations of classroom become life and natural ( Lee ,1994)". The present study aims at improving English Reading skills through board games for Iraqi EFL 4th preparatory school students.

Based on the background of the study, the researcher formulated the research questions as follow:

1. To What extent is the effectiveness of Board $\mathrm{G}$ ames in improving the reading skills of fourth preparatory students?

2. How far is the effectiveness of using Board Games on teaching reading skills for fourth preparatory students?

3. Is there "a significant difference" between the mean scores obtained by the subjects of the "experimental group" who are taught reading skills according to board games and that of the "control group" who are taught reading skills according to the prescribed method in reading skills post-test? 


\section{Theoretical Background}

Reading is the process of understanding and grasping the meaning of printed or written material, in other words. It includes a conscious strategy that leads to perception (Hassan, 2015: 3). Tizon (2013: 252) points out that reading ability plays a central role in teaching and learning success at all educational stages

It is worth mentioning that reading skill is a cognitive ability that a person can use when interacting with written text ( Kareem et al., 2019). According to D avies (1978:123), reading skills involve identifying word meaning, drawing inferences, identifying writer's technique, recognizing mood of passage, and finding answers to questions.

According to Lunzer et al. ( 1979:224), reading skills are as follows: word meaning in context, literal comprehension, drawing inferences, interpretation of metaphor, finding main ideas, forming judgments."

Reading skills, as in (G rabe 1991:98), also involve automatic recognition skills, vocabulary and structural knowledge, formal discourse structure knowledge, content/ world background knowledge, synthesis, and evaluation skills/ strategies, metacognitive knowledge and skills monitoring. "G rabe (1991:98) uses very general categories, equivalent to knowledge areas". "If reading itself is a skill, it must be possible to break this down into different levels of component skills categories." G ames provide opportunities for the student to learn and make them easy to catch the material in the classroom ( Hussein et al.,2019)

Nelson, Christopher, and Mims (2009: 1) describe board games as "a game for arranging letter that will be played by 2 or 4 people who set the point base on the score of word which is formed by letter on board game that it is forming square word/ cross word " ( Ali et al.,2019). According to Wikipedia(2020:1) board game is "a word game in which two to four players score points by placing tiles, each bearing a single letter, onto a game board divided into a 15×15 grid of squares".

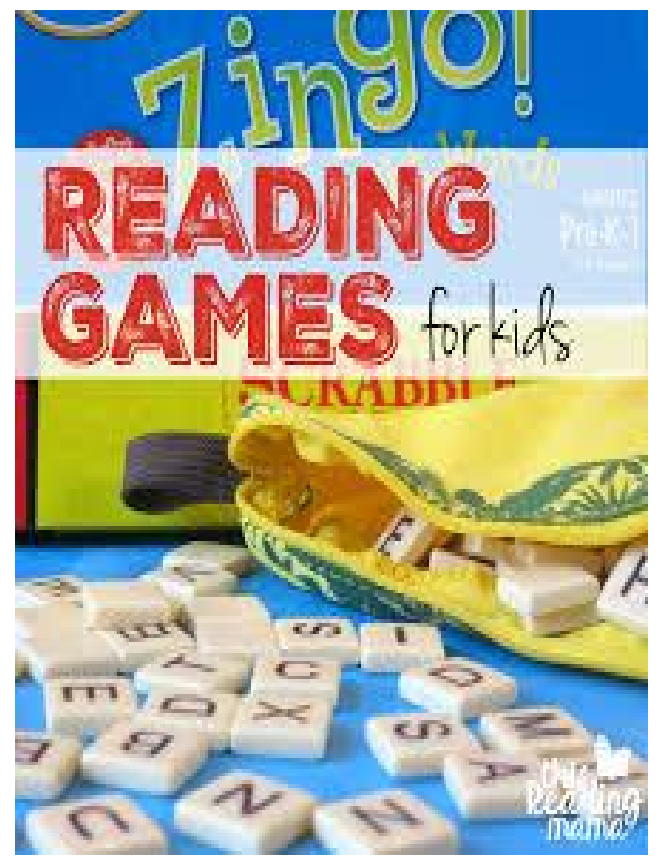

Petersen-Perlman et al. (1999: 255) propose the steps for teaching reading by a board game. "The teacher tries to attract their attention by asking some question." "It is the way to stimulate students' background of knowledge about some vocabularies from the reading passage" (Hammad et al.,2018).

" The teacher gives example by the text." "Then, the teacher asks the student to find some unknown words." "The teacher divides them into 4 groups randomly and each group consists of 7-8 students" (Abbas et al.,2018). 
"Each group has eight letters and each group has one leader." "The teacher explains the rules of the activity and gives the example."

"The teacher commands the students to begin the game." "The students try to find a new word and translate the words found." In the end, the teacher gives the evaluation".

\section{METHOD}

The present study adopts a quantitative research design. The two randomly selected samples are equated with age (in months), sex, background knowledge, and linguistic abilities.

The research method in the present study is an experimental one. Therefore, it has two variables: an independent (wordless-book strategy) and a dependent variable (the test results). The study population represents the fourth preparatory school students of the central Babylon educational directorate in the academic year (2019-2020) (Shahzadi et al., 2020). The two samples were randomly selected from Al. Warkaa Preparatory School for boys. The size of the sample is (30) fourth preparatory students are allocated into two groups, group (A) represents the control sample, and group (B) represents the experimental sample. Group (A) receives traditional language teaching, while group (B) is taught according to the Board Games Activities.

\section{Sample Equivalence}

The researcher equated the two samples concerning their social and economic status by selecting them from the same district in Karbala and the same school. The participants' age was measured by months, and those who had repeated the year were excluded from the experiment. The test scores were used to compare the two samples' linguistic backgrounds by measuring the mean scores for the first course, which turned out to be (16.3) for the control group and (16.8) for the experimental group. The parents' achievement was also taken into consideration and equated by using a statistical formula (Chi-square).

Table 1. Some variables of the equivalency of the two groups

\begin{tabular}{|c|c|c|c|c|c|c|c|}
\hline \multirow[t]{2}{*}{ Variable } & \multirow[t]{2}{*}{ Group } & \multirow[t]{2}{*}{ Mean } & \multirow{2}{*}{$\begin{array}{l}\text { Standard } \\
\text { deviation }\end{array}$} & \multirow{2}{*}{$\begin{array}{l}\text { Freedom } \\
\text { degree }\end{array}$} & \multicolumn{2}{|l|}{ T-test } & \multirow[t]{2}{*}{ Significance } \\
\hline & & & & & Calculated & Tabular & \\
\hline \multirow[t]{2}{*}{$\begin{array}{l}\text { Age } \\
\text { month }\end{array}$} & $\begin{array}{l}\text { Experimental } \\
30\end{array}$ & 65.56 & 3.65 & 59 & 0.185 & 2 & insignificant \\
\hline & Control 311 & 65.38 & 3.41 & & & & \\
\hline $\begin{array}{l}\text { 1st-course } \\
\text { English } \\
\text { achievement }\end{array}$ & $\begin{array}{l}\text { Experimental } \\
30\end{array}$ & 62.56 & 9,87 & 59 & 0.342 & 2 & insignificant \\
\hline
\end{tabular}

\section{Extraneous Variables}

Some extraneous variables may affect the course of the experiment. Therefore, the researcher made sure to equate them, too. The experiment lasted for 45 days, and none of the participants left the experiment. They all mature the same as the experiment did not last more than the intended period. Hence, the growth is unified across all members of the experiment. The students did not know they were participating in an experiment; therefore, the Hawthorne effect did not occur (D ehham:2021).

\section{Material}

The material used in the experiment is English for the Iraqi textbook for the fourth preparatory school, and the trial covered units (2\3) from the textbook. Throughout the experimental period, the researcher presented 20 lessons and set several behavioral objectives to be met across (20) lesson plans, which are proved by a jury of (15) language methodologists. 


\section{Instrument}

The achievement test is defined as the estimation of learners' information in specific content, skill, or fulfillment in a particular material, period frame, and course of study. It may also assist in distinguishing the level of students and what they need to improve and work on (Brown, 2003). The achievement test was structured by following these procedures:

1. The pre-test was intended to measure students' vocabulary achievement before implementing the experiment.

2. The post-test was designed to measure students' vocabulary retention after receiving formal instruction under the wordless-book strategy.

3. The scoring is done by giving a mark for every correct answer and a zero for any incorrect answers. The highest possible score is (30), and the lowest one is zero.

4. Test validity is achieved by validating it by a jury of 15 language specialists, who instructed some corrections and amendments, which were followed accordingly.

5. Pilot testing was done on two more schools located near the primary school in which the researcher conducted his experiment. The test items were statistically analyzed. The item difficulty ranges between (0.70-0.32), item discrimination ranges from (0.85- 0.29). The statistical results demonstrate that the test is valid.

Table 2. T-Test Results For The Study G roups Of the Test

\begin{tabular}{|c|c|c|c|c|c|c|c|}
\hline \multirow[t]{2}{*}{ G roup T } & \multirow{2}{*}{$\begin{array}{l}\text { No. of } \\
\text { students }\end{array}$} & \multirow[t]{2}{*}{ Mean } & \multirow{2}{*}{$\begin{array}{l}\text { Standard } \\
\text { deviation }\end{array}$} & T-test & & \multirow{2}{*}{\multicolumn{2}{|c|}{$\begin{array}{l}\text { Significance } \\
\text { at }(0,05)\end{array}$}} \\
\hline & & & & Calculated & Tabular & & \\
\hline Experimental & 30 & 32.90 & 4.72 & 59 & & 7.436 & Significant in favor \\
\hline Control & 30 & 24.96 & 3.53 & & & & $\begin{array}{l}\text { of the experimental } \\
\text { group }\end{array}$ \\
\hline
\end{tabular}

\section{CONCLUSION}

The researcher accepts the alternative hypothesis and rejects the null one. The statistical analysis of the results illustrates that the students of the experimental group are superior when it comes to vocabulary retention with a mean score of (28.5) and that of the control group to be (22.8) at (0.5) level of significance. The results above are in line with other research findings that suggest the superiority of wordless-book strategy as opposed to traditional teaching methods.

\section{REFERENCES}

Abbas, I. H., D ehham, S. H., \& Akbar, N. A. (2018). The psychological effects of clickers technology on English language students. Indian Journal of Public $\mathrm{H}$ ealth Research \& D evelopment, 9(10), 740. https:/ / doi.org/ 10.5958/ 0976-5506.2018.01225.1 [G oogle Search] [G oogle Scholar] [G oogle Books] [Publisher website]

Ali, D. B., D ehham, S. H., \& Hasan, A. A. N. (2019). The Effect of Using Index Cards G ames Technique on Iraqi EFL Intermediate Students' Performance on Writing Skill. Indian Journal of Public $\mathrm{H}$ ealth Research \& D evelopment, 10(1), 1093. https:/ / doi.org/ 10.5958/ 0976-5506.2019.00207.9 [G oogle Search] [Google Scholar] [Google Books] [Publisher website]

Brown, M. W . (2003). T eaching by design: U nderstanding the intersection between teacher practio and the design of curriaular innovations. [G oogle Search] [G oogle Scholar] [G oogle Books]

D avies, A . (1978). L anguage testing. L anguage T eaching, 11(3), 145-159. [G oogle Search] [G oogle Scholar] [G oogle Books] 
D ehham, S.H., Bairamani, H .K., Shreb, M .A . E nhancing iraqi E FL preparatory school students' speaking skill by using debate technique | Mejoramiento de la habilidad de hablar de los estudiantes iraquíes de inglés como lengua ex tranjera mediante la técnica de debate. U topia y Prax is L atinoamericana, 2020, 25(E x tra1), pp. 453-462. [G oogle Search] [G oogle Scholar] [Google Books]

D ehham, Sabeeha H amza. Iraqi E F L Students' A bility in A cquiring E nglish V ocabulary by Peer Instrudion T echnology.T urk ish Journal of Computer and Mathematics E ducation,2021. [G oogle Search] [G oogle Scholar] [Google Books]

D erakhshan, A ., \& Khatir, E . D . (2015). The effects of using games on E nglish vocabulary learning. Journal of A pplied L inguistics and L anguage Research, 2(3), 39-47. [G oogle Search] [G oogle Scholar] [G oogle Books]

Grabe, W. (1991). Current D evelopments in Second Language Reading Research. TE SOL Q uarterly, 25(3), 375. https:/ / doi.org/ 10.2307/ 3586977 [G oogle Search] [Google Scholar] [Google Books] [Publisher website]

Hammad, A. A., D ehham, S. H., \& Akbar, N. A. (2018). The Impact of Using Tablets on D eveloping Listening Skill \& perception as a Brain Process of EFL Primary School Pupils. Indian Journal of Public H ealth Research \& D evelopment, 9(12), 1086. https:/ / doi.org/ 10.5958/ 0976-5506.2018.01994.0 [G oogle Search] [G oogle Scholar] [Google Books] [Publisher website]

H armer, J. (2007). H ow to teach E nglish: new edition. H arlow: Pearson E ducation L imited. [G oo gle Search] [G oogle Scholar] [Google Books]

Hussein, Z. M., D ehham, S. H., \& Hasan, A. A. N. (2019). The Impact of Using Chunking Technique on D eveloping Reading Skill and Perception of Intermediate School Students. Indian Journal of Public H ealth Research \& D evelopment, 10(6), 1186. https:/ / doi.org/ 10.5958/ 0976-5506.2019.01452.9 [G oogle Search] [G oogle Scholar] [Google Books] [Publisher website]

Kamhi, A \& \& Catts, H . (2008). The language basis of reading: Implications of dassification and treatment of children with reading disabilities. In Bulter, K.\& Silliman, E . (E ds.) Speaking, Reading, and W riting in Children with L anguage and L earning disabilities: $\mathrm{N}$ ew Paradigms in Research and Practioe. [G oogle Search] [G oogle Scholar] [G oo gle Books]

Kareem, H. H., D ehham, S. H., \& Al-Wahid, M. A. (2019). The Impact of Teaching the Creative writing by FOCUS Strategy to D evelop. Indian Journal of Public $\mathrm{H}$ ealth Research \& D evelopment, 10(6), 876. https:/ / doi.org/ 10.5958/ 0976-5506.2019.01390.1 [G oogle Search] [G oogle Scholar] [G oogle Books] [Publisher website]

Lee, I. (2008). Student reactions to teacher feedback in two Hong Kong secondary classrooms. Journal of Second L anguage W riting, 17(3), 144-164. https:/ / doi.org/ 10.1016/ j.jslw.2007.12.001 [G oogle Search] [G oogle Scholar] [Google Books] [Publisher website]

Lewis, T. (1999). Research in Technology Education-Some Areas of Need. Journal of Technology E ducation, 10 (2). https:/ / doi.org/ 10.21061/ jte.v10i2.a.3 [G oogle Search] [G oogle Scholar] [G oogle Books] [Publisher website]

Lyon, G. R., Shaywitz, S. E., \& Shaywitz, B. A. (2003). A definition of dyslexia. A nnals of D yslexia, 53(1), 1-14. https:/ / doi.org/ 10.1007/ s11881-003-0001-9 [G oogle Search] [G oogle Scholar] [G oogle Books] [Publisher website]

Max on, Michelle. (2009) Teaching E nglish as a Foreign L anguage F or D ummies, A John W iley and Sons, L td, Publication. [G oogle Search] [Google Scholar] [G oogle Books]

Mik ulecky, B. S., \& Jeffries, L . (1991). Reading power: Reading faster, thinking sk ills, reading for pleasure, comprehension sk ills. A ddison-W esley Publishing Company. [G oogle Search] [G oogle Scholar] [G oogle Books]

N apa, A . P. 1991. V ocabulary development skills. Y ogyakarta: Kanisius. [G oogle Search] [G oogle Scholar] [G oogle Books] 
N elson, J., Christopher, A ., \& M ims, C. (2009). Transformation of teaching and learning. TechT rends, 53(5), 81. [G oogle Search] [G oogle Scholar] [Google Books]

Petersen-Perlman, D ., O’Brien, M., Carlson, H., \& Hilsen, L. (1999). Choreographing Partnerships: modeling the improvement of teaching and learning. Teaching in $\mathrm{H}$ igher $\mathrm{E}$ ducation, 4(2), 253-265. https:/ / doi.org/ 10.1080/ 1356251990040207 [G oogle Search] [G oogle Scholar] [G oogle Books] [Publisher website]

Praveen, S. D ., \& Rajan, P. (2013). U sing G raphic O rganizers to Improve Reading C omprehension Skills for the Middle School E SL Students. E nglish L anguage T eaching, 6(2), 155-170. [G oogle Search] [G oogle Scholar] [G oogle Books]

Raban, B., Lunzer, E., \& Gardiner, K. (1980). The Effective Use of Reading. British Journal of E ducational Studies, 28(2), 163. https:/ / doi.org/ 10.2307/ 3120578 [G oogle Search] [G oogle Scholar] [G oogle Books] [Publisher website]

Rahoomi, R. K., D ehham, S. H., \& Al-Wahid, M. A. (2019). The Impact of Reading Strategy Knowledge and Science Knowledge on D eveloping Reading Skills of School Students. Indian Journal of Public $\mathrm{H}$ ealth Research \& D evelopment, 10(10), 3028. https:/ / doi.org/ 10.5958/ 0976-5506.2019.03339.4 [G oogle Search] [G oogle Scholar] [Google Books] [Publisher website]

Read, J. (2007). Second language vocabulary assessment: C urrent pradioes and new directions. International Journal of $E$ nglish Studies, 7(2), 105-126. [G oogle Search] [G oogle Scholar] [G oogle Books]

Shahzadi, G ., Akram, M., \& D avvaz, B. (2020). Pythagorean fuzzy soft graphs with applications. In Journal of Intelligent \& F uzzy Systems (Vols. 38, Issues 4, pp. 4977-4991). IO S Press. https:/ / doi.org/ 10.3233/ JIFS-191610 [G oogle Search] [G oogle Scholar] [G oogle Books] [Publisher website]

Thornbury, S. (2002). H ow to teach vocabulary. L ongman E ssex. [Google Search] [Google Scholar] [Google Books]

Tizon, C. M. (2019). Senior High School Teachers' Perceived Level of Communication Skills and Teaching Performance. International L inguistics Research, 2(3), p17. https:/ / doi.org/ 10.30560/ ilr.v2n3p17 [G oogle Search] [G oogle Scholar] [Google Books] [Publisher website]

W arner, H., \& Brown, T. P. (2005). Scrabble® unscrambled: adult E SL students' perceptions of Scrabble@ as a classroom learning tool.. [G oogle Search] [G oogle Scholar] [G oogle Books]

Y ld dr r m, A . (2010). H e's homotopy perturbation method for solving the space-and-time fractional telegraph equations. International Journal of Computer M athematics, 87(13), 2998-3006. [G oogle Search] [G oogle Scholar] [Google Books] 